\title{
NEITHER NATIONAL BOUNDARIES NOR \\ TRANSNATIONAL SOCIAL SPACES: ACCOUNTING \\ FOR VARIATIONS OF CSR PRACTICES IN VARIETIES \\ OF CAPITALISM
}

Kenneth Amaeshi*

CSGR Working Paper 246/08

July 2008

${ }^{*}$ Lecturer, Cranfield School of Management, United Kingdom

Associate, Centre for the Study of Globalisation and Regionalisation

University of Warwick

Visiting Scholar, Said Business School, University of Oxford 
Neither National Boundaries Nor Transnational Social Spaces: Accounting for Variations of CSR Practices in Varieties of Capitalism.

Kenneth Amaeshi

CSGR 246/08

July 2008

Email: Kenneth.Amaeshi@Warwick.ac.uk

\begin{abstract}
The paper empirically re-examines the role of national institutions and trans-national social spaces in accounting for variations in CSR practices. Based on a longitudinal study of corporate social reporting in UK and Germany, the paper concludes that corporate stakeholder salience patterns are outcomes of interaction effects between national institutional boundaries and trans-national social spaces. It pushes the institutionalist frontier of research to corporate stakeholder salience - which is a precursor and intrinsic to both corporate accountability and corporate social responsibility. In addition, it opens a new vista of looking at corporate social reports - i.e. not only as artefacts of accountability, but also carriers and reflectors of national and trans-national characteristics and influences. The paper finally highlights implications of the findings for CSR and comparative capitalism research, respectively.
\end{abstract}

KEY WORDS: Comparative CSR, Varieties of Capitalism, Transnational Social Spaces 


\section{INTRODUCTION}

What accounts for variations of corporate social responsibility practices (CSR) across institutional varieties of capitalism? There is a growing interest on how CSR practices are functions of their institutional contexts, which is mainly informed by the understanding that institutions shape “... how stakeholders' interests are defined... aggregated, and represented with respect to the firm” (Aguilera and Jackson, 2003:450). This approach to deconstructing and understanding CSR practices has, in the main, drawn significantly from literature on comparative institutionalism (e.g. Matten and Moon, 2008; Campbell, 2007; Aguilera et al., 2006). Matten and Moon (2008), for instance, use their 'explicit' and 'implicit' model to explain the difference between Continental European and North American versions of CSR practices. They suggest that whilst the 'explicit' style characteristic of North American firms' CSR is vociferous about its contribution to the society - for example in provision of healthcare, education, employee welfare and other social amenities, the 'implicit' style characteristic of Continental Europe finds it less attractive to report such social provisions as contributions to the society, since these provisions are already taken care of by the national institutions in which they operate in. The UK government's national health care service (the NHS) has been providing free healthcare service to its citizenry since the 1940s and the German system has ensured that employees' welfare gets top priority in organisations through its co-determination approach to corporate governance albeit, the principle of co-determination has continued to undergo series of modifications and adaptations (Borsch, 2004).

Most of these institutionalist accounts tend to adopt a macro (national level) characteristic, which appears to suggest some kind of organisational field homogeneity within national institutional contexts. Whilst the introduction of comparative institutionalism perspective to the CSR literature is innovative and worthwhile, at least in wrestling CSR from the domineering grips of managerialist theorisations (Owen et al., 2000; Gray; 2002; O'Dwyer, 2002, 2003), it appears to under-emphasis possible heterogeneities that could exist within national institutional boundaries. These heterogeneities have been picked up by a related stream of literature that emphasises sectoral differences as main sources of variations of CSR practices (Griffin and Weber, 2006). The significance of sectors in accounting for corporate actions is also gradually permeating and unsettling the core tenets and foundations of national business systems and comparative capitalism, which are in orientation macro-centric. Scholars promoting the sector-based perspective argue that national business systems are not necessarily homogenous but are most of the time concatenations of heterogeneities, or at best 'models within models' (Deeg and Jackson, 2007:154).

An anchor for the sector-based argument is that some sectors are constitutively and uniquely trans-national social spaces ${ }^{1}$. As such, their practices cannot be fully accounted for by national institutional boundaries. In some instances, these transnational social spaces could be either more influential on corporate practices than

\footnotetext{
${ }^{1}$ Borrowing from Morgan (2001): "I take 'transnational space' to refer to an arena of social action distinct from that of the 'national' context. It is an arena of social interaction where the main modes of connection between groups cross national boundaries.... Transnational social space implies a more openended set of cross-border connections between multiple nodes in which the forms of interaction become more than simply the sum of interactions between different 'national' units; it constitutes an arena in which new social actors may emerge, which may be labelled 'transnational communities' (p.115).
} 
national institutional contexts and vice versa. The oil and gas sector in Nigeria, for instance, is heavily driven more by global than local practices (Ite, 2004, 2005; Frynas et al., 2006; Frynas, 1999), since the major actors in the sector are MNCs who tend to retain their home country influences, albeit with slight modifications (Whitley, 1999a,b). The two streams of literature on the influences of national institutional boundaries and trans-national social spaces, respectively, on corporate actions, therefore, appear to be in constant contestation in accounting for variations of CSR practices, albeit with inconclusive outcomes.

This paper empirically re-examines the role of national institutions and unique sectoral characteristics in accounting for variations in CSR practices. It leverages a core CSR practice - i.e. corporate stakeholding - as an empirical base. It draws from social account data produced by 3 major sectors (aviation, financial services and utilities) in 2 major exemplars of varieties of capitalism - UK and Germany, for comparative purposes. The main thesis of the paper is to establish to what extent either national boundaries or transnational social spaces (sectors), respectively, account for variations in corporate stakeholder salience patterns. The paper first starts with a presentation of stakeholder salience and varieties of capitalism analytical model.

\section{THEORY}

\section{Corporate stakeholding and stakeholder salience}

The stakeholder perspective to organising and managing firms is one of the major management paradigm shifts in the late last century. The theory, in its present form traceable to Freeman (1984:246), broadly and loosely defines stakeholders as "...those groups and individuals who can affect, or are affected by the achievement of an organization's purpose" - for example shareholders, employees, suppliers, government, competitors, local communities and the environment. One of the popular propositions of the stakeholder theory is the view that firms exist at the nexus of series of interdependent relationships with groups that can affect or are affected by them (Crane and Livesey, 2003). Given the infinite network of relationships firms are usually entangled in, this proposition, however, poses some fundamental challenges such as defining the boundaries of stakeholder-ship and effectively managing these relationships that often come with conflicting interests and goals. As such, Freeman (1999:234) suggests that: “...if organizations want to be effective, they will pay attention to all and only those relationships that can affect or be affected by the achievement of the organization's purposes". In other words, it is important for firms to pay attention to their important (salient) stakeholders.

Extending this instrumental view, Mitchell et al. (1997) theorised that stakeholder salience is a combination of the following factors: power, legitimacy and urgency. A stakeholder group has power when it can impose its will on the firm, especially when it controls resources needed by the firm (Pfeffer, 1981); while legitimacy implies that stakeholder demands comply with prevailing norms and beliefs. Legitimacy is achieved if patterns of organisational practice are in congruence with the wider social system (Scott 1987; Powell and DiMaggio, 1991). However, power and legitimacy can appear together, giving authority to those who have both (Weber, 1947), but they can also appear independently. Finally, urgency is a concept sustained on two elements: (1) the importance stakeholders accord their own demands; and (2) their sensitivity to how 
long it takes managers to deal with their demands (Gago and Antolin, 2004). These salient variables according to Mitchell et al. will determine how a firm responds to its stakeholders. Optimal strategic stakeholder management is, therefore, dependent on the ability of firms to identify and be responsive to salient stakeholders within their business environment.

Over the years, stakeholder management discourses and practices have, mainly, been anchored on managerial discretion. In other words, stakeholders that receive priority from management will be those whom managers perceive as highly salient (Agle et al., 1999). Theorists have recently, however, started offering complementary views to this managerialist view and interpreting firms' interactions with their stakeholders from a much broader perspective that incorporates institutional, cultural and societal contexts, into the debate. One of the approaches adopted by scholars in this field is the comparative capitalism tradition - a term used to refer "...to a diverse set of approaches and analytical frameworks with common concerns in understanding the institutional foundations of diverse national 'varieties' of business organization" (Deeg and Jackson, 2007:149-150). The varieties of capitalism (VofC) model (Hall and Soskice, 2001), as one of the variants of comparative capitalism tradition, offers a comparative framework to understand the political economy of firm behaviour and performance.

\section{Comparative capitalism perspective}

The central theme of the varieties of capitalism model is the macro-economic dichotomization of institutional contexts in which firms operate, based on such indices as legal and governance systems, sources of finance and skills, and other socio-legal indices like degree of labour unionisation and incursions of regulatory authorities. It is not uncommon in comparative capitalism literature to stylise coordinated market economies (CMEs) as stakeholder oriented and liberal market economies (LMEs) as shareholder oriented (Dore, 2000). The CME is society oriented and firms within it often tend to focus on meeting broad range of stakeholders' needs (e.g. employees, suppliers, shareholders, etc), whereas the LME is market oriented and often focuses more on meeting shareholders needs than those of any other stakeholder groups (Dore, 2000; Amable, 2003; Hall and Soskice, 2001; Fiss and Zajac, 2004; Jackson, 2005; Hancke et al., 2007). Japan and Germany are prime examples of CME whereas UK and the USA are exemplars of LME. In this regard, it is argued that different national and institutional contexts provide some sort of comparative advantages to firms within them. For example, the power, legitimacy and urgency of a unionised work group to impact on the activities of a firm would, for instance, depend on the legal institutions and societal expectations in which such unions are embedded in. Furthering their distinction of CMEs from LMEs, Hancke et al. (2007:5) state that: "The 'coordinated market economy' (CME) is characterized by non-market relations, collaboration, credible commitments, and the 'deliberative calculation' of firms. The essence of its 'liberal market economy' (LME) antithesis is one of arm's length, competitive relations, formal contracting, and supply-and-demand prince signalling”.

New waves of interpreting corporate governance and social responsibility, which have been on the increase, have also drawn insights from comparative business systems perspectives. Aguilera and Jackson (2003), for instance, presented a comparative corporate governance model which suggests that the LME differs markedly from the CME in terms of stakeholder salience. They emphasised the need to incorporate institutional dimensions to corporate governance discourse (Jackson, 2005; Aguilera 
and Jackson, 2003). Following this suggestion and in order to provide some insights and clarifications into divergent findings in this field of enquiry, this study focuses on accounting for the variations of corporate stakeholder salience patterns in two extensively stylised exemplars of the VofC model - i.e. UK (LME) and Germany (CME); and 3 trans-national sectors in these countries. These variations are explored based on the on the propositions developed below.

\section{Developing Propositions}

The VofC model holds that German and UK institutional contexts are fundamentally different in their economic coordination strategies and mechanisms. It has been argued in the extant literature on comparative capitalism that CMEs and LMEs, which German and UK economies represent respectively, are fundamentally different in such areas as ownership patterns, financial institutions, corporate governance, industrial relations and employee representation (Vitols, 2001). Following this broad-brush typology of the UK and German institutional contexts, respectively, therefore, this research proposes that:

P1: Corporate stakeholding patterns will differ between German and UK national institutional contexts.

Vitols (2001:341-42) also argues that major investors in the UK include institutional investors - investment funds, pension funds, and insurance companies who "...take a 'portfolio' approach to risk management by taking small stakes in a large number of companies" and "...are generally solely interested in a high return on their shares (and thus primarily on the profitability of the company invested in)". This investment paradigm and practice in the UK is quite unlike that of German investors who are rather "...characterized by one or more large shareholders with a strategic (rather than purely share value maximization) motivation for ownership". These shareholders are mainly banks, that the German economy has aptly been described as the 'bank-based-economy' (Amable, 2003; Fiss and Zajac, 2004). Arguably, one of the primary reasons for these banks to have stakes (or buy shares) in the firms they support is to protect their loans and not necessarily to earn income from them (Vitols, 2001). In addition to the different investment profiles of shareholders in the two economies, shareholding in the UK is known to be rather dispersed while share ownership in Germany is concentrated. It is based on this combination of shareholders' profiles and the degree of dispersion and or concentration that it has been argued that German investors and shareholders are more prone to providing 'patient capital' (Schröder and Schrader 1998; Jürgens, Naumann and Rupp 2000) than would obtain in most liberal market economies, which the UK economy aptly represents, driven by short term profits. Where and when such expected profits do not arise and or are not forthcoming, shareholders in liberal market economies are known to quickly exit. This ability and propensity for quick exit, then pushes managers to mainly aim towards profitable returns in order to keep shareholders attracted to the firms they manage. Given the divergent attention and emphasis placed on shareholders in the two economies, this study proposes that:

P2: German and UK firms will differ on the emphasis they respectively place on shareholder salience 
A second major institutional difference identified in the literature between German and UK firms is the relevance given to employees in corporate governance. In the German context, employees exercise strong 'voice' through corporatist bargaining and co-determination, which ascribes to them "...the right to negotiate key issues with management, including the hiring of new employees, introduction of new technology, use of overtime and short-working time, and in the case of mass redundancies, the negotiation of social plans (Sozialplane) covering redeployment, severance payments, and early retirement" (Vitols, 2001:343). This right derives from the German Works Constitution Act of 1972 (Betriebsverfassungsgesetz) to elect works councils. In addition to the works councils, employee representatives are also included on German supervisory boards under the 1976 Co-Determination Act (Mitbestimmungsgesetz), which applies to almost all companies with 2,000 or more employees (Vitols, 2001:343). Contrary to the rights and privileges bestowed on employees in the German context, employees do not enjoy similar rights in most liberal market economies (the UK inclusive). In the UK, labour is primarily seen as an input in the production process that should be maximised efficiently and profitably. The UK institutional context, therefore, makes it easy for firms to hire and fire employees, which in turn induces employees to go for broad skills as safety nets, whereas the German system encourages specialization of skills amongst employees (Whitley, 1999a; Hall and Soskice, 2001; Vitols, 2001). As a result, this research study proposes that:

P3: German and UK firms will differ on the emphasis they respectively place on employee groups

The roles, rights and powers of management in German and UK firms are also seen as another major source of difference between the two economies. In the liberal market economy, the functions of management are primarily a fiduciary one that requires them to maximise shareholders wealth (Berle and Means, 1932; Friedman, 1962). As such, they represent the most powerful entity between the firms and their owners and exercise strong 'voice' in organisational decisions. This is typical of the 'shareholder' model of corporate governance. The stakeholder model of corporate governance, which is typical of the German system, on the other hand gives voice to multiple stakeholders - especially employee groups, as already noted above - in how firms are run (Kelly et al., 1997). The dichotomy between the roles of management in corporate governance in Germany and the UK respectively, is further re-enforced by prevailing social understanding and expectations of firms in both institutional contexts. In Germany, for instance, firms are seen as having social obligations in addition to wealth creation, while in the UK firms are primarily instruments to maximise shareholders wealth and as such, social obligations are rather secondary. This has recently been emphasised in the 'implicit and explicit' corporate social responsibility model advanced by Matten and Moon (2008). In this regard, this study, also, proposes that:

P4: German and UK firms will differ on the emphasis they respectively place on management 
However, the growing emphasis on consumerism and consumer welfare and orientation is not restricted to any capitalist system. It has in itself assumed a global dimension, which highlights a postmodern expression of consumer sovereignty and a 'de-traditionalized' consumer society (Sturdy, 1998:27). The 'customer is king' philosophy has become one of those marketing fads and fashions that have continued to trail the growth and expansion of the service economy (Egan and Shipley, 1995; Sturdy and Fleming, 2003; Jones and Fleming, 2003). Although there is an implicit assumption of an inherent positive (normative) orientation towards consumers in coordinated market economies, the liberal market economies in their sole quest for profit have also turned to the consumers, albeit, in an instrumental fashion. Attention to customer needs has been identified as a key survival strategy in contemporary globalised economy (Deshpande et al, 1993), and the diffusion of this ideology has been sustained through organisational practices of Transnational Corporations (Abrahamson, 1991; Siu and Darby, 1995), management consultants and the international media (Bloomfield and Danieli, 1995; Jackson, 2001). Given the globalised nature of customer service discourse and pervasive international influences on different institutional contexts, structures and governance mechanisms, this research study proposes that:

P5: German and UK firms will adopt similar direction of emphasis on customers if exposed to similar international influences

Tied to these propositions is also the need to understand how patterns of corporate stakeholding salience (if any) are made manifest on the sector levels; and the interrelation between characteristics of sector and national institutional contexts. It is expected that the unpacking of these configurations and interrelations will throw some light to understanding how stakeholder salience is implicated in the dynamics of both industry and institutional contexts.

\section{METHODOLOGY}

\section{Selection of Firms}

The firms chosen for the study are selected systematically to minimise bias in the research data. Some of these biases include company size, country/ region, listing status and industry, which previous studies had sought to control for as well (for example, see: Meek et al., 1995; Gamble et al., 1996; Griffin and Weber, 2006). To minimise these biases, a list of top UK and German firms is drawn from the 2006 edition of Fortune Global 500 companies list. The use of Fortune Global 500 list and similar lists as selection indices and empirical sites is well established in the literature (e.g. Jose and Lee, 2007; Kolk, 2003). The list produced thirty eight (38) UK firms and thirty five (35) German companies.

\section{Data Sources and Collation}

The primary research data source for this research study is corporate social reports, because they have become signals for 'good' corporate citizenship (Matten and Crane, 2005) and stakeholder orientation (Crane et al., 2004) as well as stakeholder accountability (Gray, 2002; Gray et al., 1995a,b; Unerman, 2000) and reputation 
artefacts (Hooghiemstra, 2000). A key point of this study, therefore, is that firms use corporate social reports to signal their stakeholder salience. Following this understanding, corporate social reports, therefore, provide pragmatic and novel empirical sites to study corporate stakeholder salience patterns and practices - especially as "....identities and interests of stakeholders vary cross-nationally' (Matten and Moon, 2004:14).

The seventy three (73) firms were contacted for hardcopies of their social, environmental and sustainability reports from 2000 to 2006. After a matching process of availability of social reports across sectors in UK and Germany, the following sectors were randomly chosen in alphabetical order: Aviation, Financial Services and Utilities. This is to control for extraneous variations, as much as possible, so that identified variations between sectors could be pinned down to differences in national institutional contexts.

In order to further substantiate the validity of data drawn from corporate social reports, an online survey was administered to all the 73 firms in the sample frame, which basically asked them to rank the identified stakeholders used in the study in their order of importance (i.e. salience) to the firms - through a forced ranking order. The idea behind this forced ranking order is to identify possible patterns of stakeholder salience in the different institutional and sectoral contexts and see how they compare to those generated from corporate social reports. Similarity in patterns will confirm the validity of both sources of data, while dissimilarity may either suggest low validity and or suggest incongruence between corporate 'talk' (survey) and 'text' (corporate social reports) (Dore, 2000).

The online survey was emailed to senior executives of all the 73 firms (38 UK and 35 German firms) in our sample, who are involved in corporate social responsibility, governance and or accountability functions, to further enhance and augment the robustness of the conclusions reached from the corporate social report data of the 3 main sectors of the study - Aviation, Finance and Utilities. The survey recorded an average total response rate of $61 \%$.

\section{Data Coding and Analyses}

The corporate social reports were content analyzed using a validated coding scheme. In all, the corporate social reports - which amounted to a total of 3,822 pages of report - generated a cumulative total of 2,986 images, 1,833 graphics, and 125 pages of Chairman (management) Statement (CS) and 872 paragraphs of these Chairmen (management) Statements. The social reports were then rigorously coded page to page, image to image; graphics to graphics and paragraphs to paragraphs, based on a coding criteria.

Data generated from content analysis of documents and online survey, respectively, were analysed using multivariate analysis of variance (MANOVA). According to Ellis and Haase (1987), multivariate models are suitable for analysis of data from researches that give rise to more than one dependent variable, as in this study with the following dependent variables - Customers, Employees, Management, and Shareholders stakeholder groups.

\section{Findings}

The multivariate statistical analysis of variance was run on the data using the SPSS statistical software. Results of the analysis, in a nutshell, show that corporate 
stakeholder salience patterns as reflected through corporate social reports are significantly $(p<0.0001)$ influenced by sectoral and institutional contexts, both in isolation and in conjunction with each other, whilst the online survey data confirm that both sector and institutional contexts have influence (at a significant level of $p<0.05$ ) on corporate stakeholder salience.

The outcomes of MANOVA from both sources of empirical data suggest that the UK and German institutional contexts generate distinctive patterns of corporate stakeholder salience profiles, as well as the different sectors used in this study. This makes it more interesting to argue for an interaction effect between sectoral and institutional influences on corporate stakeholder salience patterns; but more would be needed from the data to further unpack the implications of these interactive effects on the predictions of the varieties of capitalism for the UK and German institutional contexts, which constitute the main propositions of this research study. In order to do this, the research leverages outcomes of the multivariate analysis of data from corporate social reports, which is the main data source of this study, to search for betweensubjects effects as shown in the table below.

\section{INSERT TABLE 1 ABOUT HERE}

From the result tables above, both country and sector level data offered what could be considered contradictory results in isolation, when matched against the postulations of the varieties of capitalism model. In other words, neither of the results in isolation confirms the postulations of the varieties of capitalism model. The country level data suggest that German and UK firms differ only on Consumers stakeholder salience, which is rather directly opposite to the propositions of this study. The sector level data on the other hand suggest that the sectors differ only on Employees and Management stakeholder salience. However, it is difficult to read off varieties of capitalism postulations from sector level data in isolation of country influences. A further probing into the joint sector/country influences on patterns of stakeholder salience, shows that the German and UK institutional contexts interact with sector level influences to shape patterns of corporate stakeholder salience profiles. In a nutshell, the table below highlights the implications of the influences of sector, country and sectorcountry interactions on corporate stakeholder salience patterns, expressed through UK and German corporate social reports, in support of the propositions derived from the varieties of capitalism model employed in this research study.

\section{INSERT TABLE 2 ABOUT HERE}

As a result, it could be concluded therefore, that corporate stakeholder salience patterns are reflections of meso (organisational fields) and macro (national contexts) institutional characteristics.

\section{DISCUSSION}

The broad literature on the role of business in the society has recently witnessed a burgeoning of works accounting for variations in one or more of the following: corporate social responsibility, stakeholder management, corporate accountability and governance either from a sectoral perspective (e.g. Gray et al., 1995a; Kolk, 2003; 
Griffin and Weber, 2006) and or national contexts perspectives (e.g. Maignan, 2001; Chapple and Moon, 2005; Jackson, 2005; Amaeshi et al., 2006; Matten and Moon, 2008). These studies often tend to either bracket sectors or national contexts in their accounts, depending on which of the two they are focusing on. What this research study suggests in more specific terms is that such dichotomisation of sectors and national contexts in the study of business and society interactions could lead to lopsided conclusions that ignore and consequently undermine the simultaneous interactive influences of the two levels of governance (or socio-economic coordination) on corporate practices. In addition to this possible oversimplification of interactive institutional influences on corporate practices, there is also the tendency to deconstruct national contexts as summations of sectors within national contexts. This in itself, could as well be misleading in that sectors are not necessarily and exhaustively contained by national contexts, but could span across national borders and as such exhibit characteristics and attributes different from those of national contexts.

This conclusion fits well with the main finding of this study, which suggests that corporate stakeholder salience patterns - as expressions of firm behaviours - are implicated in the dynamic interactions between national and sectoral peculiarities. However, the ability of a sector to expand beyond its national boundaries through internationalisation offers an insightful and interesting dimension to unpacking the simultaneous joint sectoral and institutional influences on corporate practices, as is suggested by the findings of this research study, which has some research implications for the study of business and society interactions.

Good examples of such trans-national sectors will include the aerospace and automotive (Amaeshi et al., 2007), the oil and gas sectors (Frynas et al., 2006) and the financial services (Faulconbridge et. al., 2007) to mention but a few. The influences of these sectors are usually global and could be more powerful in certain instances than national institutional contexts (a good example here will be the role of multinational dominated sectors in some developing countries - the oil and gas in Nigeria, for instance - Uwem, 2005; 2004; Frynas, 1999). Also, in their comparative study of the interaction between the institutional contexts of UK and German corporate law firms, on one hand, and the international markets for legal services, on the other, Morgan and Quack (2005) found that contrary to the view that law firms are highly determined by the national distinctiveness of professional and legal systems of the institutional contexts in which they are embedded, that "... the internationalization of UK and German law firms bears traces of institutional legacies as well as signs of pathmodification, and that international markets for legal services may be more differentiated and less dominated by Anglo-Saxon law firms and conceptions of law than has been so far recognized" (emphasis, mine, p.1765). These trans-national sectors provide trans-national social spaces (Morgan, 2001, 2006; Morgan and Quack, 2005) in which trans-national organisations draw from to interact, shape and or reconfigure national institutional contexts, where possible.

Notwithstanding, these transnational sectors are not isolated entities. They rather constitute complex networks and also have the possibility of cross-sectoral influences and are as well susceptible to national modifications and translations (Abrahamson, 1991; Czarniawska and Joerges, 1996). These inter-sectoral, inter-country and transsector-country interactions are schematically shown below. Patches of grey on the schematic indicate areas of interactions between trans-national sectors and national 
contexts, which could account for heterogeneity within national models (Crouch, 2005; Crouch et al., forthcoming). Accordingly, Morgan (2006:24-25) argues that:

...the national and the transnational clearly co-exist but what is interesting is how they interact and co-evolve. Whilst our social spaces are becoming more transnational, our capacities to resolve the problems emerging from this do not seem to be keeping pace. Many powerful actors still follow their national patterns and this leads them to interact with emergent transnational institutions in ways that exacerbate difference and conflict.

\section{INSERT FIGURE 1 HERE}

However, these changes occur in time. If applied to this research study, this temporal dimension implies that corporate stakeholder salience profiles are not static but are dynamically shaped by the characteristics of both the national institutional framework and the (trans-national) organisational field of the firm. By extension, therefore, corporate social reporting is responsive to these changing patterns of institutionally influenced corporate stakeholder salience, which reflects in the varied dominant themes of corporate social reporting over time. The environment, for instance, dropped-off the social reporting list in the 1980s and surfaced again in the 1990s (Gray, 2002, 2001). In the study of USA firms and environmental Lober et al (1997:67) found that "...Employees were the most frequently cited target group, indicated by $82 \%$ of the companies, followed by shareholders at $74 \%$. Customers and government agencies were cited by over one-half of the report issuers as key audiences. Environmental groups and the local communities were targeted by over $40 \%$ of the reports. The general public was a target of $35 \%$ of the reports". While these cyclical changes in social reporting over the decades have been attributed to the subjection of social accounting and its associated activities (e.g. social audits) to the political whims of corporations (Gray, 2001), it has also been advanced that the increasing trend in social reporting by firms is linked to the social pressures on them since the 1970s to be more socially responsible in their practices (Gray, 2002). Jones (1999) cite the example of the US constitutional rights that were originally directed at white male property owners, but over time come to defuse to other stakeholder groups (e.g. women and ethnic minorities) because "...the basic articles of the Constitution and Bill of Rights created discursive space within which subordinated groups could act strategically to avail themselves of the same rights accorded to white men" (p.167).

Notwithstanding, these changes are more likely to be sticky rather than rapid or step changes given that large scale and far-reaching changes would require "...considerable institutional restructuring and realignment of major societal interests...[which] are unlikely to develop simply as a consequence of internationalization, or to occur within one or two decades" (Whitley, 1999a:134). In relation to institutional changes relating to corporate governance structures, Vitols (2001:339) argues that "...these developments can be clearly characterized as incremental - rather than fundamental - changes in existing ownership, employee representation, and top management institutions". In other words, it is advisable for 
comparative business and society studies to be aware of these dynamic interactions; recognise them in their accounts and find insightful ways to accommodating them in the interpretations of their research findings.

Finally, one of the key findings of this study, leveraging the varieties of capitalism analytical framework, is that corporate stakeholder salience patterns are reflections of series of complex interactions between national institutional frameworks and (trans-national) industry influences on firms. This finding is not limited to the understanding of corporate stakeholder salience but also has implications for current debates and efforts to fine-tune comparative business models - particularly the varieties of capitalism model. In this regard, the varieties of capitalism model as an analytical 'agenda' (Hancke et al., 2007) for understanding variations of political economies could be theorised as a reflection of the dynamism between interdependent layers of influences - one at specific (trans-national) sector levels, and the other arising from interactions between different (trans-national) sectors within a particular national context to generate national patterns of corporate stakeholder salience. Although the varieties of capitalism model is often presented as a firm centred approach (Hancke et al., 2007:5) - in which "[I]t is assumed that firms behave according to the rules provided for them by the specific institutional arrangements, which thus co-ordinate and 'govern' them" (Crouch et al., forthcoming) - it appears to abstract from these emergent interactive patterns of corporate stakeholder salience at the micro-level to typify national political economies, while at the same time paying less or minimal attention to possible heterogeneity within same national political economies and or influences from trans-national social spaces (Morgan, 2001, 2006).

The need to account for heterogeneity within the varieties of capitalism model has come at no better time than when the national culture school of thought is being hacked at its very foundations for taking within-nations heterogeneities for granted and assuming that national boundaries are fairly static/stable and almost impermeable (see Hofstede's and McSweeney's debates over implications of the national culture construct in social science research in Human Relations, 2002). One of the points made by McSweeney (2002a) in his arguments against typologies of countries based on 'national cultures' is the tendency of such approaches to undermine national heterogeneities and then subsume them under socio-geographic constructions of nation states, which may not necessarily constitute credible representation of differences between and within institutional contexts. The same line of criticism, therefore, could be levelled against the varieties of capitalism model if it continues to ignore endogenous sources of national system transformation and 'within-system' diversity (Coates, 2005; Boyer, 2005; Crouch, 2005; Panitch and Gindin, 2005); and instead apply a broad-brush approach to characterisation of national political economies, even though it claims to "...give micro-foundations to a more general theory of cross-national capitalist organization and adjustment" (Hancke et al., 2007:5). In this vein, Crouch et al. (forthcoming) observe and caution that: "Local specialisms that depart from the logic of a national system ... suggest that the nation state is not necessarily always the most important level for determining the institutional environment of business. It is important that research pay attention to these instances". 


\section{REFERENCES}

Abrahamson, E. (1991). Managerial fads and fashions - the diffusion and rejection of innovations. Academy of Management Review, 16, 3, 586-612.

Agle, B. R., Mitchell, R. K., and Sonnenfeld, J. A. (1999). Who Matters to CEOs? An Investigation of Stakeholder Attributes and Salience, Corporate Performance, and CEO Values, The Academy of Management Journal, 42(5):507-525

Aguilera, R. and Jackson, G. (2003) The Cross-National Diversity of Corporate Governance: Dimensions and Determinants, Academy of Management Review, 28 (3), pp. 447- 465.

Aguilera, R. V., Williams, C.A., Conley, J. M. and Rupp, D. E. (2006). Corporate Governance and Social Responsibility: a comparative analysis of the UK and the US, Corporate Governance: An International Review 14 (3), 147-158

Amable, B. (2003). The diversity of modern capitalism. Oxford: Oxford University Press

Amaeshi, K., Adi, B. C., Ogechie, C. and Amao, O. O. (2006). Corporate Social Responsibility in Nigeria: Indigenous practices or Western influences?, Journal of Corporate Citizenship (winter edition).

Amaeshi, K., Scarbrough, H., and Moore, R. (2007). Institutional co-entrepreneurship and the transnationalisation of the EU aerospace sector: a discourse analytic perspective Technology, Innovation and Institutions Working Paper Series, the University of Alberta School of Business, Canada http://www.business.ualberta.ca/tcc/working_papers.htm

Berle, A. A. and Means, G. C. (1932). The Modern Corporation and Private Property. New York, Macmillan Publishing Co.

Bloomfield, B. P. and Danieli, A. (1995). The role of management consultants in the development of IT. Journal of Management Studies, 32, 1, 23-46.

Borsch, A. (2004). Globalisation, shareholder value, restructuring: the (non)-transformation of Siemens. New Political Economy, 9(3):365-387

Boyer, R. (2005). How and why capitalisms differ. Economy and Society, 34(4):509-57

Campbell, J. L. (2007). Why would corporations behave in socially responsible ways? An institutional theory of corporate social responsibility. Academy of Management Review, 32(3): 946-967

Chapple, W., and Moon, J. (2005). Corporate social responsibility (CSR) in Asia: a seven-country study of CSR web site reporting. Business and Society, 44(4):415-39

Coates, D. (2005). Paradigms of Explanation. In: D. Coates (ed.), Varieties of Capitalism, Varieties of Approaches. Houndmills Basingstoke, UK and New York: Palgrave Macmillan, pp.139-59

Crane A, and Livesey S. (2003). Are You Talking to Me? Stakeholder Communication and the Risks and Rewards of Dialogue. In Unfolding Stakeholder Thinking vol II: Relationships, communication, reporting and performance, Andriof J, Waddock, S, Rahman S S, Husted B (eds). Sheffield: Greenleaf; 39-52.

Crane, A., Matten, D., and Moon, J. (2004). Stakeholders as Citizens? Rethinking Rights, Participation, and Democracy. Journal of Business Ethics, 53(1-2):107-122

Crouch, C, (2005). Capitalist Diversity and Change: Recombinant Governance and Institutional Entrepreneurs, Oxford University Press

Czarniawska, B., \& Joerges, B. (1996). Travel of ideas. In: Translating organizational change. B. Czarniawska and G. Sevon (eds), 13-48. Berlin: De Gruyter

Deeg, R., Jackson, G. (2007): The State of the Art: Towards a More Dynamic Theory of Capitalist Variety, Socio-Economic Review, 5, 149-179. 
Deshpande, R., Farley, J. U. and Webster, Jr., F. E. (1993). Corporate Culture, Customer Orientation, and Innovativeness in Japanese Firms: A Quadrad Analysis, Journal of Marketing, 57(1):23-27

Dore, R. ( 2000). Stock Market Capitalism: Welfare Capitalism, Japan and Germany versus the AngloSaxons. Oxford: Oxford University Press.

Egan, C. and Shipley, D. (1995). Dimensions of customer orientation - an empirical investigation of the UK financial services sector. Journal of Marketing Management, 11, 807-16.

Ellis, M. V., and Haase, R. F. (1987). Multivariate analysis of variance. Journal of Counselling Psychology, 34(4), 404-413.

Faulconbridge, J., Engelen, E., Hoyler, M., and Beaverstock, J. (2007). Analysing the Changing Landscape of European Financial Centres: The Role of Financial Products and the Case of Amsterdam. Growth and Change 38 (2), 279-303.

Fiss, P. C. and Zajac. E. J. (2004). The Diffusion of Ideas over Contested Terrain: The (Non)adoption of a Shareholder Value Orientation among German Firms. Administrative Science Quarterly, 49: 501-534.

Freeman, R. E. (1984). Strategic management: A stakeholder approach. Boston: Pitman

Freeman, R. E. (1999). Response: Divergent stakeholder theory. Academy of Management Review, 24(2):233-236

Friedman, M. (1962). Capitalism and Freedom. Chicago IL, University of Chicago Press.

Frynas, J. G. (1999). Oil in Nigeria: con ${ }^{-i c t}$ and litigation between oil companies and village communities, Munster, Hamburg and London: Lit Verlag

Frynas, J. G., Mellahi, K., and Pigman, G. A. (2006). First mover advantages in international business and firm-specific political resources. Strategic Management Journal, 27(4): 321-345

Gago, R. F. and Antolin, M. N. (2004). Stakeholder salience in corporate environmental strategy. Corporate Governance, 4(3):65-76

Gamble, G. O., Hsu, K., Jackson, C., and Tollerson, C. D. (1996). Environmental disclosures in annual reports: An international perspective. The International Journal of Accounting, 31(3):293-331

Gray, R. (2001). Thirty years of social accounting, reporting and auditing: what (if anything) have we learnt? Business Ethics: A European Review, 10(1):9-15

Gray, R. (2002). The social accounting project and Accounting, Organizations and Society: privileging engagement, imaginings, new accountings and pragmatism over critique? Accounting, Organizations and Society, 27:687-708

Gray, R., Kouchy, R., and Lavers, S. (1995b). Methodological themes: constructing a research database of social and environmental reporting by UK companies. Accounting, Auditing $\mathcal{E}$ Accountability Journal, 2:78-101

Gray, R., Kouhy, R., and Lavers, S. (1995a). Corporate social and environmental reporting: a review of the literature and a longitudinal study of UK disclosure, Accounting, Auditing EF Accountability Journal, 2:47-77

Griffin, J. J. and Weber, J. (2006). Industry social analysis: examining the beer industry. Business E Society, 45:413-440

Hall, P. A. and Soskice, D.(Eds) (2001). Varieties of Capitalism - The Institutional Foundations of Comparative Advantage. Oxford: Oxford University Press.

Hancke, B., Rhodes, M., and Thatcher, M. (2007). Introduction: beyond varieties of capitalism. IN: B. Hancke, M. Rhodes and M. Thatcher (Eds.), Beyond Varieties of Capitalism: conflict, contradictions, and complementarities in the European economy. Oxford: Oxford University Press 
Hooghiemstra, R. (2000). Corporate communication and impression management - new perspectives why companies engage in corporate social reporting. Journal of Business Ethics, 27:55-68

Ite, U. E. (2004). Multinationals and corporate social responsibility in developing countries: a case study of Nigeria. Corporate Social Responsibility and Environmental Management, 11(1): 1-11

Ite, U. E. (2005). Poverty reduction in resource-rich developing countries: what have multinational corporations got to do with it? Journal of International Development, 17(7): 913-929

Jackson, B. (2001). Management Gurus and Management Fashions. London: Routledge.

Jackson, G. (2005). Stakeholders under Pressure: corporate governance and labour management in Germany and Japan, Corporate Governance: An International Review 13 (3), 419-428

Jones, M. T. (1999). The institutional determinants of social responsibility. Journal of Business Ethics, 20:163-179

Jones, M. T. and Fleming, P. (2003). Unpacking Complexity Through Critical Stakeholder Analysis The Case of Globalization, Business Society.2003; 42: 430-454

Jose, A. and Lee, S. (2007). Environmental Reporting of Global Corporations: A Content Analysis based on Website Disclosures. Journal of Business Ethics, 72(4):307-321

Jürgens, U., and Naumann, K., Rupp, J. (2000). Shareholder Value in an Adverse Environment: The German Case. Economy and Society 29: 54-79.

Kelly, G., Kelly, D., and Gamble, A. (Eds.) (1997). Stakeholder capitalism, Houndmills, Basignstoke: Macmillan

Kolk, A. (2003). Trends in sustainability reporting by the Fortune Global 250. Business Strategy and the Environment, 12(5):279-291

Lober, D. J., Bynum, D., Campbell, E. and Jacques, M. (1997). The 100 plus corporate environmental report study: A survey of an evolving environmental management tool. Business Strategy and the Environment, 6(2):57-73

Maignan, I. (2001) Consumers' Perceptions of Corporate Social Responsibilities: A Cross-cultural Comparison, Journal of Business Ethics 30: 57-72.

Matten, D. and Moon, J. (2008). 'Implicit' and 'Explicit' CSR: A conceptual framework for a comparative understanding of corporate social responsibility. Academy of Management Review

Matten, D., and Crane, A. (2005). Corporate Citizenship: Towards an Extended Theoretical Conceptualization. Academy of Management Review, 30(1): 166-179.

Matten, D., and Moon, J. (2004). 'Implicit' and 'Explicit' CSR: A conceptual framework for understanding CSR in Europe. ICCSR Research Papers Series - ISSN1479-5124 No. 292004 http://www.nottingham.ac.uk/business/ICCSR/pdf/ResearchPdfs/29. 2004.pdf visited July 1, 2005

McSweeney B. (2002b). The essentials of scholarship: A reply to Geert Hofstede. Human Relations, 55(11):1363-1372

McSweeney, B. (2002a). Hofstede's model of national cultural differences and their consequences: A triumph of faith - a failure of analysis. Human Relations, 55(1):89-118

Meek, G. K., Roberts, C. B., and Gray, S. J. (1995). Factors Influencing Voluntary Annual Report Disclosures by U.S., U.K. and Continental European Multinational Corporations. Journal of International Business Studies, 26(3):555-572.

Mitchell, R., Agle, B., Wood, D. (1997). Towards a theory of stakeholder identification: Defining the principle of who and what really counts. Academy of Management Review 22(4), 853-86 
Morgan, G. (2001). Transnational communities and business systems, Global Networks 1 (2), 113-130.

Morgan, G. (2006) Transnational Actors, Transnational Institutions, Transnational spaces: The role of law firms in the internationalisation of competition regulation, in Djelic, M. - L. and Sahlin-Anderson, K. (eds) Transnational Regulation in the Making. Cambridge: Cambridge University Press.

Morgan, G. and Quack, S. (2005). Institutional Legacies and Firm Dynamics: The Growth and Internationalization of UK and German Law Firms. Organization Studies, 26 (12):1765-1786

O'Dwyer, B. (2002). Managerial perceptions of corporate social disclosure: An Irish story, Accounting, Auditing $\mathcal{E}$ Accountability Journal, 15(3):406-436

O'Dwyer, B. (2003). Conceptions of corporate social responsibility: the nature of managerial capture. Accounting, Auditing and Accountability Journal 16(4):523-557.

Owen, D. L., Swift, T. A., Humphrey, C. and Bowerman, M. C. (2000). The new social audits: accountability, managerial capture or the agenda of social champions? European Accounting Review, 9(1):81-98

Panitch, L. and Gindin, S. (2005). Euro-capitalism and American Empire. In: D. Coates (ed.), Varieties of Capitalism, Varieties of Approaches. Houndmills Basingstoke, UK and New York: Palgrave Macmillan, pp.139-59

Pfeffer, J. (1981). Power in Organizations. Boston, MA:Pitman

Powell, W. W., and DiMaggio, P. J. (1991). The New Institutionalism of Organizational Analysis. Chicago: University of Chicago Press

Schröder, U., and Schrader, A. (1998). The Changing Role of Banks and Corporate Governance in Germany: Evolution Toward the Market. Pp.17-34 in Competition and convergence in financial markets : the German and Anglo-American models, edited by Stanley W. Black. New York: Elsevier Science.

Scott, W. R. (1987). The Adolescence of Institutional Theory. Administrative Science Quarterly, 32(4):493-511

Siu, N. Y. M. and Darby, R. (1995). Management Development and Customer Orientation: the Case of Foreign Joint Ventures in the People's Republic of China. Asia Pacific Business Review, 2(2):60-74

Sturdy, A. and Fleming, P. (2003). Talk as Technique - A Critique of the Words and Deeds Distinction in the Diffusion of Customer Service Cultures in Call Centres, Journal of Management Studies 40 (4), 753-773.

Sturdy, A. J. (1998). Customer care in a consumer society: smiling and sometimes meaning it. Organization, 5, 1, 27-53.

Unerman, J. ( 2000). Reflections on Quantification in Corporate Social Reporting Content Analysis Accounting, Auditing $\mathcal{E}$ Accountability Journal, 13 ( 5): 667- 680

Vitols, S. (2001). Varieties of corporate governance: comparing Germany and the UK. In: P. A. Hall and D. Soskice (Eds.). Varieties of Capitalism: the institutional foundations of comparative advantage, Oxford: Oxford University Press pp. 337-360

Weber, M. (1947). The theory of social and economic organization. Glencoe, Ill.: The Free Press

Whitley, R. (1999a). Divergent Capitalisms. The Social Structuring and Change of Business Systems. Oxford: Oxford University Press.

Whitley, R. (1999b). Firms, institutions and management control: The comparative analysis of coordination and control systems. Accounting, Organizations and Society, 24:507-524 


\section{Appendix}

Table 1: Tests of Between-Subjects Effects using data sets from corporate social reports

\begin{tabular}{|ll|r|r|r|}
\hline Source & Dependent & df & F & Sig. \\
\hline Sector & Variable & 2 & 4.955 & .010 \\
& Employees & 2 & .139 & .871 \\
& Shareholders & 2 & 1.494 & .232 \\
& Consumers & 2 & 3.240 & .046 \\
& Management & 1 & 1.022 & .316 \\
& Employees & 1 & .721 & .399 \\
& Shareholders & 1 & 8.846 & .004 \\
& Consumers & 1 & .592 & .445 \\
& Management & 2 & 2.724 & .043 \\
Sector * Country & Employees & 2 & 4.073 & .022 \\
& Shareholders & 2 & 1.674 & .196 \\
& Consumers & 2 & 3.968 & .024 \\
\hline
\end{tabular}

Table 2: Implications of the influences of sector, country and sector-country interactions on corporate stakeholder salience patterns

\begin{tabular}{|c|c|c|c|c|c|}
\hline & $\begin{array}{l}\text { STAKEHOLDER } \\
\text { SALIENCE/ } \\
\text { ISSUES }\end{array}$ & DETAILS & SECTOR & COUNTRY & $\begin{array}{l}\text { SECTOR/ } \\
\text { COUNTRY } \\
\text { JOINT } \\
\text { INFLUENCES }\end{array}$ \\
\hline $\begin{array}{c}\text { Proposition } \\
\text { 1: }\end{array}$ & & $\begin{array}{l}\text { Corporate stakeholding patterns } \\
\text { will differ between German and } \\
\text { UK national institutional contexts. }\end{array}$ & NA & $\nabla$ & NA \\
\hline $\begin{array}{c}\text { Proposition } \\
2:\end{array}$ & Shareholder & $\begin{array}{l}\text { German and UK firms will differ } \\
\text { on the emphasis they respectively } \\
\text { place on shareholder salience of } \\
\text { different stakeholder groups in } \\
\text { corporate social reports }\end{array}$ & 冈 & 可 & $\square$ \\
\hline $\begin{array}{c}\text { Proposition } \\
\text { 3: }\end{array}$ & Employees & $\begin{array}{l}\text { German and UK firms will differ } \\
\text { on the emphasis they respectively } \\
\text { place on employee groups in } \\
\text { corporate social reports }\end{array}$ & $\square$ & 凶 & $\square$ \\
\hline $\begin{array}{c}\text { Proposition } \\
4:\end{array}$ & Management & $\begin{array}{l}\text { German and UK firms will differ } \\
\text { on the emphasis they respectively } \\
\text { place on management in corporate } \\
\text { social reports }\end{array}$ & $\nabla$ & 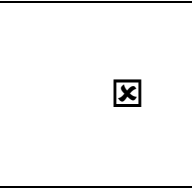 & $\nabla$ \\
\hline $\begin{array}{c}\text { Proposition } \\
5:\end{array}$ & Customers & $\begin{array}{l}\text { German and UK firms will adopt } \\
\text { similar direction of emphasis on } \\
\text { customers in their corporate social } \\
\text { reports if exposed to similar } \\
\text { international influences }\end{array}$ & $\square$ & 可 & $\square$ \\
\hline
\end{tabular}


Figure 1: Country Sector Interactions

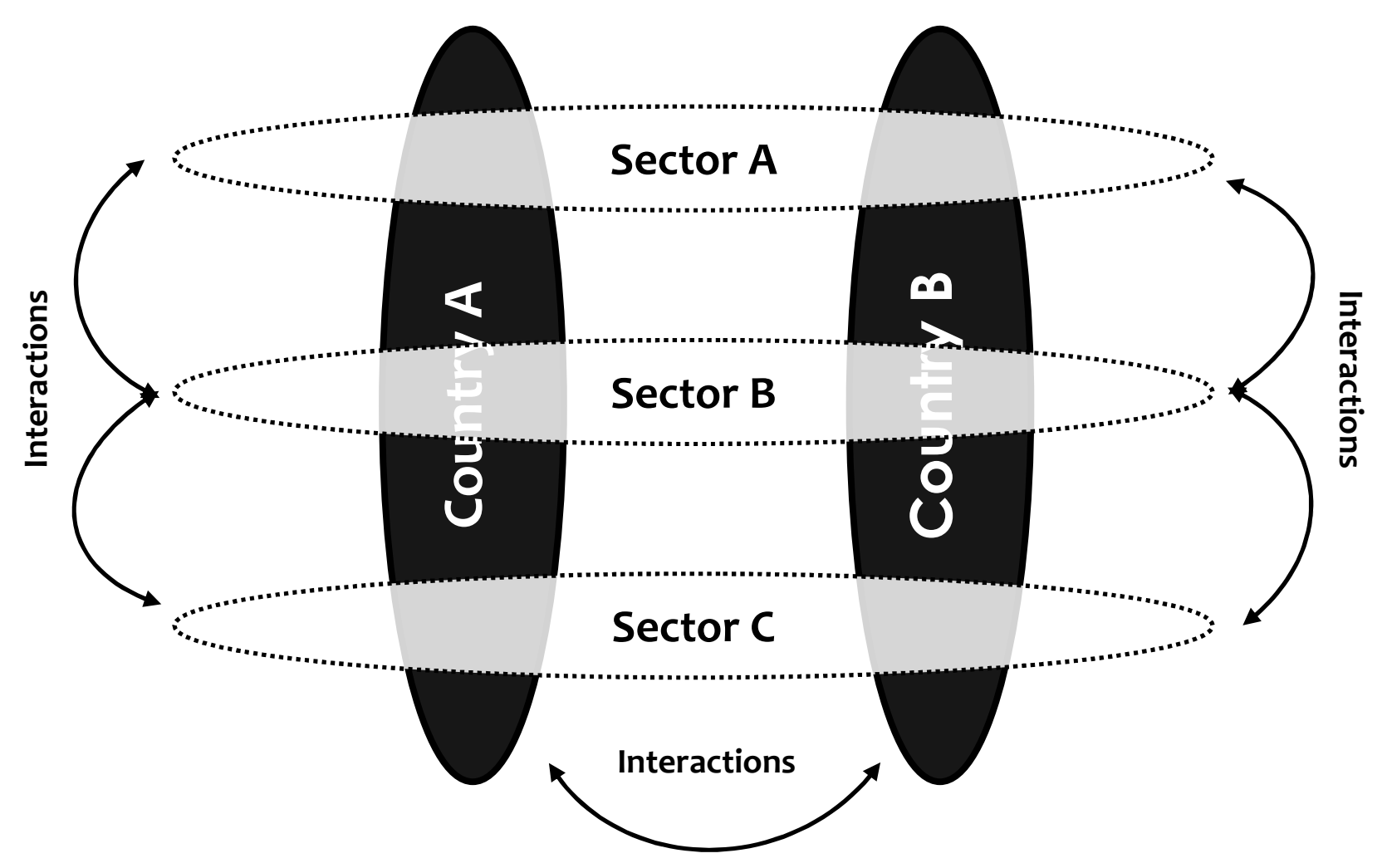




\section{$\underline{\text { CSGR Working Paper Series }}$}

216/06 December

217/07 February

218/07 February

219/07 February

220/07 February

221/07 March

222/07 March

223/07 March

224/07 March

225/07 May

226/07 May

227/07 May

228/07 May

229/07 June

230/07 June

231/07 June

232/07 July
Marcus Miller and Lei Zhang

Fear and Market Failure: Global Imbalances and "Self-insurance"

Catherine Hoskyns

Linking Gender and International Trade Policy: Is Interaction Possible?

Dilip K. Das

South Asian Free Trade Agreement: Prospects of Shallow Regional Integration

Vanesa Weyrauch

Weaving Global Networks: Handbook for Policy Influence

Yuji Tamura

Preferences for Immigration Restriction and Opinions about Immigrant's Economic Impacts

Dania Thomas and Javier García-Fronti

Good Faith in Sovereign Debt Restructuring: The Evolution of an Open Norm in 'Localised' Contexts?

Michela Redoano

Fiscal Interactions Among European Countries: Does the EU Matter?

Jan Aart Scholte

Civil Society and the Legitimation of Global Governance

Dwijen Rangnekar

Context and Ambiguity: A Comment on Amending India's Patent Act

Marcelo I. Saguier

Global Governance and the HIV/AIDS Response: Limitations of Current Approaches and Policies

Dan Bulley

Exteriorising Terror: Inside/Outside the Failing State on 7 July 2005

Kenneth Amaeshi

Who Matters to UK and German Firms? Modelling Stakeholder Salience Through Corporate Social Reports

Olufemi O. Amao and Kenneth M. Amaeshi

Galvanising Shareholder Activism: A Prerequisite for Effective Corporate Governance and Accountability in Nigeria

Stephen J. Redding, Daniel M. Sturm and Nikolaus Wolf History and Industry Location: Evidence from German Airports

Dilip K. Das

Shifting Paradigm of Regional Integration in Asia

Max-Stephan Schulze and Nikolaus Wolf

On the Origins of Border Effects: Insights from the Habsburg Customs Union

Elena Meschi and Marco Vivarelli

Trade Openness and Income Inequality in Developing Countries 
233/07 July

234/07 September

235/07 October

236/07 November

237/08 March

238/08 March

239/08 March

241/08 March

242/08 January

243/08 April

244/08 May
Julie Gilson

Structuring Accountability: Non-Governmental Participation in the AsiaEurope Meeting (ASEM)

Christian Thimann, Christian Just and Raymond Ritter

The Governance of the IMF: How a Dual Board Structure Could Raise the Effectiveness and Legitimacy of a Key Global Institution

Peter I. Hajnal

Can Civil Society Influence G8 Accountability?

Ton Bührs

Towards a Global Political-Economic Architecture of Environmental Space

Kerstin Martens

Civil Society, Accountability And The UN System.

Diane Stone

Transnational Philanthropy, Policy Transfer Networks and the Open Society Institute.

Dilip K. Das

The Chinese Economy: Making A Global Niche

Dwijen Rangnekar

Geneva rhetoric, national reality: Implementing TRIPS obligations in Kenya.

Priscillia E. Hunt

Heterogeneity in the Wage Impacts of Immigrants.

Ginaluca Grimalda, Elena Meschi

Accounting For Inequality in Transition Economies: An Empirical

Assessment of Gloabisation, Institutional Reforms, and Regionalisation.

Jan Aart Scholte

Civil Society and IMF Accountability

\section{Centre for the Study of Globalisation and Regionalisation}

University of Warwick

Coventry CV4 7AL, UK

Tel: $+44(0) 2476572533$

Fax: +44 (0)24 76572548

Email: csgr@warwick.ac.uk

Web address: http://www.csgr.org 